\title{
Lessons from science fiction: Frederik Pohl and the robot prosumer
}

It wasn't so hard to be a proper, industrious consumer if you worked at it, he reflected. It was only the malcontents, the ne'er-do-wells and the incompetents who simply could not adjust to the world around them (Pohl 1975, p. 118).

The diverse fields of business, management and marketing have long explored the concept of the 'prosumer' - the producer-consumer who not only consumes those products produced by industry, but also has some hand in their creation (Toffler 1980; Ritzer 1993; Ritzer and Jurgenson 2010; Ritzer 2015). But while the term 'prosumer' is credited to futurist Alvin Toffler and his book The Third Wave (1980), the concept he describes (and that which Ritzer et al. adapt) is also central concern of science fiction, which has much to offer our understanding of modern-day prosumption and is not limited by the language and limitations of purely scientific academic discourse. Notable examples include Bernard Wolfe's Limbo (1952) and Kurt Vonnegut's Player Piano (1952), both of which predate Ritzer and modern theories on prosumption by several decades, and interrogate the dehumanization of workers and the impact of computerization on human behaviour. However, while these early post-war novels are incredibly useful, the most significant voice in this area is the oftenoverlooked Frederik Pohl, whose worlds of robot prosumers, hyper-consumption and ecological disaster are particularly relevant today, given our social and political climate, and the rise of 'surveillance capitalism' (Zuboff 2019) - the real world manifestation of the dystopias that Pohl and his contemporaries describe.

In The Space Merchants (1952), co-authored with CM Kornbluth, the world is run by advertising firms who exploit consumers for profit and pride themselves on their ability to shape human desire. This manipulation reaches its height as star copysmith Mitchell Courtenay is tasked with trying to recruit colonists for a one-way trip to the inhospitable planet Venus. However, it is only when he loses his identity and has his elite status revoked that Courtenay is forced to see the world through the eyes of those citizens who are trapped in the spiralling debt of work. Meanwhile, in the short story 'The Midas Plague' (1954), the main character Morey Fry exists in a world where social status is linked to levels of consumption. In order to meet his consumption quota, Fry sets his robot servants to consuming products on his behalf, leaving him free to enjoy the 'luxury' of not needing to consume. This revelation sets the tone for another story, 'The Man Who Ate the World' (1956), in which the lack of human affection as a child leads Sonny Trumie to develop into a dangerously psychotic consumer in his adult life, whose hyper-consumption threatens the stability of the local area. 
In each of these works, Pohl seeks to satirise the mindless robot-like behaviour of human consumers. But more than that, his tales also offer a word of warning, and point to the challenge of the prosumer in our modern-day world. If robots are both producing and consuming, as they are in 'The Midas Plague', then what's left for the human? If the process of consumption becomes so standardized that it can be mass-produced in a mindless, robotic fashion, then what agency does the consumer possess? Is there any space left for the human at all? In this paper, I will explore the background of the robot in science fiction and will then explore some of Pohl's most interesting robotic prosumers, and the lessons they leave us. Thus, I will argue that science fiction isn't just a useful tool, but rather a vital resource for social theorists, providing a speculative framework through which to imagine possible futures and the lasting impacts of consumption that go beyond describing the world as it is, and move into the realms of what the world may become.

\section{The human robot}

Science fiction has long been interested in the concept of the human, and what it means to be human in a world of machines. Philip K. Dick's novel, Do Androids Dream of Electric Sheep? (1968) is perhaps one of the most famous examples, with its blockbuster Hollywood movie spin-offs, Blade Runner (1982) and Blade Runner: 2049 (2017). In the original novel, the protagonist Rick Deckard is tasked with 'retiring' (killing) rogue Nexus 6 androids who have taken home on Earth. But as the story unfolds, it becomes increasingly difficult to tell human and robot apart, to the point where it transpires that Deckard himself is an android replicant, and the machines he is sent to kill have more 'humanity' than many of the humans he is supposed to protect.

Of course, the origins of the robot go back much further than the work of Philip K. Dick. Indeed, the first recorded instance of the word 'robot' in the English language can be traced back to the 1920s and the play R.U.R. by Czech writer, Karel Čapek. The play, also known as 'Rossum's Universal Robots', centres on a factory that makes artificial people, called roboti (robots), to perform the tasks of human beings. They are not mechanical beings as such, but rather organic machines who look somewhat like human beings and do the work previously carried out by humans. Indeed, Čapek even describes his robots as 'humans capable of work but not thinking' (Horáková and Jozef Kelemen 2008), revealing a deliberate blurring between the two subjectivities, and pre-empting the dehumanization of factory workers that was to emerge alongside Fordist thinking in the US.

In this way, Čapek's early robots were never really mechanical 'robots' as modern interpretations might suggest, but rather they were much closer to humans stripped of agency to behave in a machine-like way. Thus, if the robot-like workers of Čapek's play are also compelled to consume the same goods that they produce (as many workers invariably are), then it follows that robot-like consumption must be a logical consequence of robot-powered mass-production. This then raises the important question of whether it is even possible to reinsert the human in the process of 
consumption. If human subjectivity is now so closely aligned with that of the robot (such as Čapek and others suggest), then have we already crossed the line of no return?

\section{The many worlds of Frederik Pohl}

Frederik Pohl (1919-2013) is one of the most important names in science fiction, with a career spanning nine decades, from his first poem published in Amazing Stories (1937), through to his final book, All the Lives He Led (2011). As well as numerous short stories, essays and collections, Frederik Pohl is perhaps best known for his novels Man Plus (1976), Gateway (1977) and Jem (1979), as well as his famous collaboration with CM Kornbluth, The Space Merchants (1952). He was also a highly influential editor, with his early work editing pulp magazines Astounding Stories and Super Science Stories (1939-1943), before later taking the reins at Galaxy Science Fiction and If magazines (19601969).

As Michael R. Page suggests, all this and more 'helped shaped the field of science fiction in significant ways', such that 'One can hardly claim to know science fiction without in some way having to encounter Frederik Pohl' (2015). Indeed, following his death in 2013, Science Fiction Studies published an obituary for Pohl, claiming that: 'He was the closest thing to a "Renaissance man" the genre has ever produced' (Latham 2014). Not only that, but just like the greatest artists of the Renaissance period, so Pohl's influence can still be felt to this day, with many writers owing some debt to his work, and his lasting legacy as an agent, editor and author, laying the groundwork for the genre as it stands today.

At the heart of much of Pohl's writing lies an intense interest in the role of the machine, and a concern that the boundaries between the human and the machine might be becoming blurred. In Man Plus, the protagonist Roger Torraway undergoes a biological transformation in order to survive a dangerous mission to Mars. However, while the narrator presents Torraway's story much like a scientific report, the twist reveals that the narrator is in fact a machine, and that machines have been guiding Torraway's life all along. Not only have the machines been guiding Torraway, but the twist also implies that we readers have also been equally mis-led by the machinic narrator that has filtered our perceptions and the way we understand the plot.

Meanwhile, in Gateway and its sequels, protagonist Robinette Broadhead is faced with the challenge of uncovering truths about a series of ancient alien artefacts scattered throughout the galaxy. When he unlocks some of the secrets of the Heechee technology, Broadhead discovers that the Heechee are able store the personalities of the dead within machines, and uses the same technology to merge with the machines in order to preserve his mind after bodily death. But while the machines in Gateway provide a solution to the problems faced by many of the characters, they also pose a significant challenge and even a threat, as Broadhead is so heavily reliant on technology he doesn't 
fully understand, and even in the later novels, puts himself fully in the hands of AI who may not always be working in his best interest.

But if Pohl is concerned with the blurring of the human and the machine, he is just as concerned with the fact that humans themselves often behave much like machines, and seek to find ways to manipulate and control others. Drawing on his experience as an advertising copywriter, Pohl often introduces elements of marketing theory and psychology to demonstrate that humans don't necessarily need machines in order to behave in a machine-like way. Three of his most important works in this regard are his co-authored novel The Space Merchants (1952), and his short stories, 'The Midas Plague' (1954), and 'The Man Who Ate the World' (1956). While each of these works shares Pohl's central concern with human-machine relations, they also explore elements of Pohl's environmentalism, and concern with the impacts of mass-consumption on human life - a key concern of the early post-war period with the dawn of the computer age heralding a raft of new technologies and consumer goods. While machines, robots and automated technologies play an important role in each of these three works, they each blur the boundaries between human and machine, and interrogate the role of humans and machines in the cycle of production and consumption. It is not enough that machines produce and humans consume, but rather that humans become more and more like machines, such that consumption itself becomes a mechanical process, stripping consumers of agency and creating a dystopian world in which the only 'freedom' is the freedom not to consume, and is a freedom limited to the very rich.

\section{The Space Merchants}

Among Frederik Pohl's vast catalogue of work, The Space Merchants (1952) stands out as one of his most important novels, with a long legacy, and implications that are still relevant to this day. Written together with his long-time friend and writing partner, CM Kornbluth, The Space Merchants was published during a time of much social change in the US, with McCarthyism and the Korean War (1950-1953) serving as a backdrop to fears around the power of global corporations and the rise of surveillance culture. Indeed, the novel also draws heavily on Pohl's own experience as a writer and editor, extrapolating ideas around the manipulation of consumers, and the ethical implications that such manipulation entails.

The Space Merchants follows the story of Mitchell Courtenay, a star-class copywriter at the advertising firm Fowler Schocken Associates. Early on in the novel, Courtenay is assigned one of the company's most valuable accounts, and is tasked with recruiting colonists to leave the overcrowded Earth and set up a new home on the planet Venus. However, only one man, Jack O'Shea, has ever completed a mission to Venus, and it soon transpires that the planet is all but uninhabitable, and it would take many generations for the planet to be terraformed to a reasonable standard. Thus, any colonists who sign up for the one-way trip would arrive to find they had been sold a terrible lie. And 
yet Courtenay is not bothered by the ethical implications of his work, and instead extols his abilities as a copywriter to sell anything to anyone - including life on an inhospitable planet.

However, things take a dramatic turn when Courtenay is kidnapped in Antarctica and has his identity stolen, by what he believes is a rival firm. He is then forced to work in a Chlorella harvesting plant, and is confronted with the lives of the consumers he used to play a part in exploiting. To escape the plant, Courtenay uses his skills as a master copywriter to produce propaganda for a group of revolutionaries, turning his skills against the advertising agencies that put him in the plant in the first place. This leads to a final confrontation with those who stole his old life away, and he is forced to come to terms with the fact his friends of old may never have been friends at all, and those he thought were enemies were not enemies either.

One of the most significant themes in The Space Merchants is the recurring pattern of production and consumption that Courtenay facilitates in his role as an ad man, and which he is then forced to experience in person when his role as star copysmith is suddenly taken away. Indeed, when Courtenay is set to work in the Chlorella plant, he soon gets caught up in a vicious spiral of production and consumption where he is forced to spend his low wages on goods to help make his work bearable. In this way, he gets ever more ensnared in the debt of work. As Courtenay observes:

I'd been paid again, and my debt had increased by eight dollars. I'd tormented myself by wondering where the money went, but I knew. I came off shift dehydrated, as they wanted me to be. I got a squirt of Popsie from the fountain by punching my combination - twenty-five cents checked off my pay-roll. The squirt wasn't quite enough so I had another-fifty cents (Pohl and Kornbluth 1952, 74-75).

Here, the very necessity of 'doing work' to pay his debts leads Courtenay to spend more money on goods to help him live to work another day. This cycle is such that he even has to pay interest on the money he borrows in order to avoid dehydration (75). Such is the clawing, invasive nature of the cycle that Courtenay himself feels unable to escape the ongoing debt, as he is stripped of agency and his behaviour become more and more like that of a machine - a producing-consuming robotic prosumer.

Ironically, it is only by using his skills a copywriter that Courtenay is able to turn the tide on his oppressors. However, he is only able to do this because he started life outside of the prosumption cycle, and so has the knowledge and insight to see the cycle for what it really is. Without the skills granted by his former life as a copysmith, it is likely that Courtenay may never have realized the true nature of his position, and he certainly wouldn't have been able to climb the ranks of the revolutionaries so quickly. In this way, Pohl and Kornbluth draw attention to the fundamental link between production and consumption, and the way workers are tied to a debt from which they can never break free. For Pohl and Kornbluth at least, the 'crime' is not just that employees are forced to 
consume the output of their own production, but that they're not even aware that they are trapped in the first place.

In many respects The Space Merchants pre-empts much of the real-life criticism that was to emerge around the same period. This criticism includes Vance Packard's seminal work The Hidden Persuaders (1957), a book which the author claims to shed light on 'the chilling world of George Orwell and his Big Brother' (Packard 1957, 5). However, unlike the fictional works of Orwell and Huxley, Packard depicts a real-life dystopia where marketers use psychological techniques to influence human behaviour to the point where consumers often don't even realize they're being influenced in the first place. In a way then, The Space Merchants dramatizes Packard's critique, and packages it within a fictional world that makes it far easier for the general public to understand (Luckhurst 2005, 111), extrapolating some of Pohl's own experiences as a writer and editor. However, part of the power of The Space Merchants is that it becomes quite difficult to tell the fictional world of Pohl and Kornbluth apart from the non-fictional world of Packard, as science fiction blurs with science fact, and truth becomes much stranger than fiction. Indeed, Packard even hints at a future where scientists use 'biocontrol' to direct human behaviour, such that human subjects become much like the robots in Karel Čapek's play R.U.R.

What's worrying from Pohl and Kornbluth's perspective, is that here, it's not just the producers that become robotized like the factory production-line workers, but rather that consumers are also transformed into robots, to obey in unthinking fashion, and not even realize the extent to which they are being controlled. If the producers and the consumers are nothing more than robots, then where does this leave the human?

\section{The Midas Plague}

Pohl explores some of the implications of The Space Merchants in his short story 'The Midas Plague', first published in Galaxy magazine in 1954. 'The Midas Plague' is set in a not-too-distant future of over-production where energy is cheap, and citizens' success is measured by their capacity to consume goods and services. The story follows the journey of protagonist Morey Fry as he seeks to make his way in a world where consumption is seen as a civic duty, and citizens are put under great pressure to maintain their consumption quotas for fear of losing their social status. Early on in the story, Fry is even treated by a psychologist for his underwhelming consumption, where his doctor tells him 'the most important single anti-social phenomenon [is the] failure to consume' (Pohl 1975, 142).

As psychological interventions fail to 'cure' Fry of his under-consumption, he decides to adjust the programming of his servant robots so that they consume goods on his behalf. He then returns home one day to find: 
There was the butler-robot, hard at work, his copper face expressionless. Dressed in Morey's own sports knickers and golfing shoes, the robot solemnly hit a ball against the wall, picked it up and teed it, hit it again, over and again, with Morey's own clubs. Until the ball wore ragged and was replaced [...] (Pohl 1975, 144).

While robots may present an easy solution to his consumption problem, Fry is left wondering, 'what's in it for the robots?' After all, he could just as easily be using general wear-and-tear machines to do the job instead of thinking machines. This leads him to add 'satisfaction circuits' to the robots' hardware so that they get a kick of satisfaction every time they wear something out. This then creates a cycle in which the robots feel more and more satisfied by consumption, leading them to worker harder and harder, while Fry is free to live his life without the pressure to consume. As Fry observes: 'Satisfaction leads to more work - and better work - and that means more goods, which they can be made to want, which means incentive to work, and so on, all around' (Pohl 1975, 160).

As a result of his discovery, Morey Fry is declared a genius by the scientific community who praise him for solving the problem of consumption. The story ends with the decision to provide a robot duplicate for every member of the family in order that the robot consume on their behalf. This then leads to the comical situation where Fry only discovers that his wife is pregnant when his family receives an extra robot ready to consume on the new baby's behalf.

Clearly, there are many crossovers between the mass-consumption depicted in 'The Midas Plague', and the world of advertising control described in The Space Merchants. While Morey Fry may seek to escape the world of mass-consumption by setting his robots to consume on his behalf, so he merely exposes the robot-like behaviour of humans as they are trapped in a never-ending cycle of consumption. Here, it's not enough that his robots consume on his behalf, but that they get some small satisfaction from each product they wear out, prompting them to work harder and faster at consuming the same goods they have some hand in creating in the first place. In many ways, this mirrors the exact same conundrum exposed in The Space Merchants where workers are trapped in a world in which they must work in order to consume, and the products of their labour are directly linked to those same items they consume. However, in 'The Midas Plague' this concept is taken one stage further as it opens up the question of satisfaction, and the way robotic prosumers are compelled to continue the production-consumption cycle at all costs, often without realizing that they are caught in a system not of their own making.

In this way, the robots of 'The Midas Plague' desire their own repression, much as philosophers Gilles Deleuze and Félix Guattari describe in their seminar work $A$ Thousand Plateaus: Capitalism and Schizophrenia (1987). In the chapter, 'Micropolitics and Segmentarity', the philosophers explore the way segmentary power structures exert influence over the lives of subjects. They then go on to critique the workings of bureaucracy that sustain these segmentary power structures, and make the origins of power impossible to recognize or define (250). This brings about a 
situation where individuals wilfully submit to the complex workings of power imposed upon them. According to Deleuze and Guattari, this is because:

Desire is never separable from complex assemblages that necessarily tie into molecular levels, from micro-formations already shaping postures, attitudes, perceptions, expectations, semiotic systems, etc. Desire is never an undifferentiated instinctual energy, but itself results from a highly developed, engineered setup rich in interactions: a whole supple segmentarity that processes molecular energies and potentially gives desire a fascist determination (251).

When they talk of 'fascism' here, Deleuze and Guattari refer very much to fascism with a small ' $\mathrm{f}$ ', for they refer in this instance to the microfascism applied on the level of the individual, bound up within a complex assemblage of power structures at work upon them. The key here, is that the power structures are so complex that it is difficult for any normal human subject to assign responsibility to a single act. To explain this point, Deleuze and Guattari draw on the example of the office manager whose power is diffuse across the organization, and impossible to locate to a single point (250).

This theme of desire and social power structures comes up time and time again in the science fiction of the early post-war period, and coincides with rapid computerization and the expansion of the surveillance state. One of the most important works of science fiction in this area is Daniel Keyes' Flowers for Algernon which first appeared as a short story in 1959, and as a novel in 1966. In both versions of the story, the protagonist Charlie Gordon undergoes a scientific experiment to transform him into a genius. As he undergoes transformation from a man of low intelligence to a genius who far surpasses the scientists who work on him, Charlie starts to notice the computer-like internalized microfascisms that shape his desire and compel him to behave in a certain way (Ryder 2019). In this case, the example of Charlie Gordon reflects much of what Deleuze and Guattari describe in $A$ Thousand Plateaus - namely, that Charlie's microfascistic desire is rooted in the many complex interactions with those around him, leading him to oscillate between human and machine-like subjectivities as he wilfully submits to others in order to 'fit in' and avoid censure (Ryder 2019). In this way, Charlie's desire isn't so much an individualized desire as such, but rather, it forms part of a much broader, more complex network of power relations that can never be traced to a single point.

This observation is also reflected Pohl's short story, 'The Midas Plague'. In the story, Morey Fry installs 'satisfaction circuits' in his robots in order to bring about a positive response to consumption. However, this is just the same as the positive compulsion described by Deleuze and Guattari brought about by microfascistic desire. According to this argument, human subjects produce on account of their desire to consumer, and consume goods and services as consumption is constituted as the main objective of work, despite the fact that consumption is also tied to work itself (much as Courtenay discovers in the Chlorella plant). This leads the very act of consumption to perpetuate the cycle of production-consumption indefinitely. This process is especially problematic as self-imposed 
microfascistic desire can never be met in full, as there is always more to do, and human desires are mirrored and replicated by subjects within the social milieu.

Clearly, this situation is absurd, and Pohl is quick to make fun of the perversity of the situation and just how close The Space Merchants and 'The Midas Plague' come to reflecting the realities of everyday life. While Pohl may have been writing in the 1950s, the issues he engages with are even more pressing today than they were in the early days of the Cold War, for the consequences of over-production and over-consumption are having a well-documented effect on the present-day world, from social inequalities and injustice to pollution and climate change - just as Pohl (and others) predicted. Indeed, if the works of Pohl tell us anything, it is that social theorists and policy makers need to take science fiction and other speculative fictions far more seriously to help prepare for the world of tomorrow. It is not enough to adopt a reactionary approach to new technologies, but rather to take a speculative view and consider where these developments may lead before the event, in order to head off some of the policy making challenges that arise when new technologies become too big and too powerful to control.

For example, one might well consider Pohl's concern that consumption might one day become a social institution - much as he suggests in 'the Midas Plague'. This prediction has be born out in the rise of social media, with the rise of Facebook and Instagram in particular, serving to both create and sustain a cycle never-ending robotic prosumption, where users gain social status by sharing their latest purchases alongside holiday snaps and other symbols of 'success'. This process is so invasive, and so fundamental to the way social media sites operate, that it is almost impossible to regulate behaviour as social media sites don't 'produce' anything as such - much rather, they facilitate a process by which users themselves become the product and are central to the platforms' ongoing success.

Furthermore, Facebook and its contemporaries have grown so rapidly in recent years that they are now huge multinational operations that span across international borders, and exercise power far beyond that of many states - much like Fowler Schocken Associates in The Space Merchants. Indeed, their power of influence arguably extends far beyond that of states, for their size and status makes them almost impossible to regulate, while they continue to exercise subtle influence over the daily lives of their users, from curated news feeds and targeted adverts to uncensored extremist content and the spread of fake 'news'.

Not only has science fiction long predicted the dangers of corporations-as-states, but has also long warned against the damaging effects of the production-consumption cycle on users who are stripped of agency and trapped in a cycle of repetitive, meaningless free work. While the examples cited in this paper don't predict social media specifically, they do pose a challenge to the way neoliberal policies effectively facilitate and condone technologies that standardize methods of production and consumption such that human subjects are subjectively constituted much like machines, providing 'free work' to multinational corporations that make huge profits at the expense of 
personal freedoms and privacy. Indeed, in this way, so social media users are perhaps the example par excellence of modern-day robotic prosumption, mindlessly producing and consuming content, while social media firms sell their data and target them with ads that then in turn feed back into the cycle of prosumption from which users struggle to escape through 'fear of missing out'.

\section{The Man Who Ate the World}

But what of the psychological impact of such behaviour? Who is affected, and what are the consequences? Frederik Pohl attempts to address some of these questions in 'The Man Who Ate the World' (1956), a short story set in the same world as 'The Midas Plague' that in many ways stands as its spiritual successor.

The story tells the tale of Sonny Trumie, a young man whose parents took away his teddy bear as a child, telling him 'Sonny, you're a big boy now. We aren't as well off as other people, but you have to help us [...] We all have to do our part' (11). This lack of human affection leads Trumie to turn into a compulsive consumer as an adult; an obese, psychologically damaged man who hides away on a small island with a group of companion robots for company. His mass-consumption puts a drain on the local infrastructure, and the authorities worry that his dangerous behaviour might upset the delicate balance of the world. As such, they send in a group of officials, including a psychologist, to try and break the cycle of self-destruction. On spotting the cause of Trumie's compulsions, one of the team decides to dress up as a giant teddy bear in order to confront him and make him face up to his traumatic past. The story ends with Trumie falling asleep in the teddy bear's arms.

While Roger Luckhurst argues that the psychological compulsion to consume in this story is 'directly linked to the traumatic changes in capitalism wrought by mechanization' $(2005,112)$, it is also true that Trumie's issues run far deeper than mere mass production, as he himself is transformed into a consuming machine. While the availability of goods is certainly impacted by the mechanization of the means of production, the demand for goods is painted in similarly robotic terms. In this case, Trumie is 'programmed' by his parents from a very early age, at the expense of human affection. Here, Trumie's missing bear doesn't just represent a loss of childhood, or even a nostalgia for days gone by, for it also acts as a focus through which readers can understand Trumie's plight and the humanity 'stripped away' by his compulsion to consume at all costs.

While a course of psychological treatment fails to fix Morey Fry of his lack of consumption in 'The Midas Plague', in this tale, psychological treatment does appear to restore Trumie to a more balanced state. Whether or not this is sufficient, or if it even works in the long term, is left to the reader's imagination. However, one would suspect that Pohl is not wholly convinced by the solution he proposes, for the very concept of the giant teddy bear is quite absurd, suggesting Pohl is mocking not only the problem, but the solution to the problem as well. Hyper-consumption is such an absurd 
situation that the only answer is to dress someone up in a teddy bear costume and give all of the robotic consumers a great big hug.

\section{The robot prosumer}

Though Alvin Toffler may have introduced the word 'prosumer' to the public imagination in his book The Third Wave (1980), the concept of the producer-consumer had long been in use, though with something of a different analysis to Toffler's own. While the word 'prosumer' in itself is certainly effective as a descriptor (Ahluwalia and Miller 2014), its application and indeed, its implications, still leave much to be desired. For Toffler, the prosumer was always a positive notion, 'heal[ing] the historic breach between producer and consumer' (1980, 24 - my emphasis), and leading to what Toffler claimed would be 'the first truly humane civilization in recorded history' (25). However, he clearly fails to interrogate the notion of prosumption and the potential (negative) ramifications of the world of prosumption he describes. For a man so keen to look to the future, it seems strange that he shouldn't have thought to look back, just a few decades, to the future-gazing of science fiction authors who were already dealing with similar issues and trying to come to terms with the real-world implications of hyper-consumption and the inhumane effects of exploitative prosumption and the ever-growing debt of work. While Pohl and Kornbluth describe a world of working-to-consume and consuming-to-work in The Space Merchants, Toffler by contrast seems oblivious to the social harm his vision for the future also implies.

Indeed, not only do Pohl and Kornbluth pre-date Toffler by some three decades, but they also anticipate the rise of prosumption culture, and the ever-increasing exploitation of both the worker and the consumer, and the damaging social, economic and ecological impacts a world of hyperprosumption can have. In the case of Pohl specifically, he locates the origins of prosumption in the cold logic of rationalism, and the mass-production of goods, and the further mass-production of consumers ready to put these goods to use. In this way, Pohl also pre-dates George Ritzer's book The McDonaldization of Society (1993) - a work that draws on Toffler's term in its analysis - by at least 40 years, and provides many relevant and useful insights that still rings true to this day.

One of the most significant implications of Frederik Pohl's work is the ever-increasing robotization of consumers, such that consumers are effectively 'programmed' by ad agencies and marketeers in order to manipulate behaviour. The real-world implications of this robotic programming have been well documented, and would become a significant cause for concern in the years that followed. Vance Packard for example, writes of 'manufacturing consent' in The Hidden Persuaders (1957), while Robert MacNeil explores the link between television and politics in his aptly-titled book The People Machine (1968). In many respects, these observations mark a continuation of the work of the likes of Walter Lippmann, writing as early 1922 about the impact of news media on shaping the way people think. These challenges became even more pronounced in the post-war period with the 
rise of computer technology and colour television bringing the world of science fiction into people's homes. It wasn't enough that people were being 'programmed' by newspapers and written adverts such as Lippmann describes, but by a whole array of diverse media such that the shaping of human behaviour itself was becoming a form of productive process, much as Herman and Chomsky describe in their influential study, Manufacturing Consent (1988).

But of course, Herman and Chomsky were writing long after science fiction writers had started to grapple with these issues and cast them in revealing light. Without the speculative frameworks of Orwell, Huxley, Dick, Pohl et al, it's not even certain these manipulations would have necessarily come to light at all, and certainly not in the same way. At the very least, these writers built a platform on which to open up an academic discourse around the way in which people were being slowly transformed into the robots described most famously by Czech writer Karel Čapek. Certainly, these speculative frameworks are more relevant than they've ever been, and provide a means through which to interrogate the ongoing rationalization of everyday life.

This is most apparent today in the consumer-driven nature of social networking sites. It's not enough that consumers produce and consume the content that provides these companies with ad revenue, but that they also sustain and replicate the discourse of consumption, with social media platforms built specifically to encourage the sorts of content sharing that promote mass-consumption, be it pictures of holidays, cars, houses, new trainers, or meals at fancy restaurants. The result is a world of artificial constructs in which users themselves become emblems of consumption, while at the same time producing and maintaining the system that constrains them. In this way, they are much like the consumers of 'The Midas Plague' where a failure to consume, and failure to demonstrate consumption, leads to a loss of social status.

This robot-like, conformist behaviour continues to haunt society as robot prosumers are fast becoming the beating (mechanical) heart of modern-day life. In this way, prosumption, and the related theory of McDonaldization, is as much a theory of social change as it is a theory of consumption (Ritzer and Miles 2019, 4), for everyday life itself is changing to adapt to altered modes of consumption.

One prominent example is Airbnb, an online marketplace that allows users to either offer or arrange lodging, acting as a broker for users who serve as both producer and consumer of goods, while passing on commission to Airbnb for each booking that is made. The result is that consumers themselves are able to rent rooms in convenient locations while also making money from their own homes when they happen to be away. It's not enough that consumers buy properties to own and live in, but that these same properties become a site of production, from which consumers become landlords of a kind, generating income for the producer-consumer while also completely transforming the landscape of the hotel economy, such that anyone can now effectively make money out of the place they happen to live. 
Another example of prosumption-as-social-change is the taxi app Uber, a platform that offers work to drivers and facilitates the booking of said taxis through its platform, making it quick and easy to order an Uber taxi from anywhere. What's so interesting in the case of Uber is how its business model subtly blurs producer and consumer into a single form. Once users have ordered a taxi and arrived at their destination, they can 'rate' their driver and write a review. This helps boost the taxi driver's rating and improve their chances of getting better fares. But similarly, the driver can also opt to review the consumer, rating them on their behaviour and even potentially blocking them from future travel. In this way, the Uber app doesn't just standardize the product (the taxi journey), but also the consumption of said product, making the consumers themselves a form of product that feeds back into the production-consumption cycle. Such is the ubiquity of 'Uber ratings' now that these ratings are often even seen as a badge of honour among consumers, and a high Uber rating is seen as something to brag about on social media and (in this author's experience), even on dating apps as a semi-satirical way to sell one's reliability to other daters.

But beyond the likes of Airbnb and Uber, another interesting development in the realm of digital prosumption is the rise of mixed or augmented reality video games, such as Ingress and Pokémon GO. In these games, users wander the (real) world, and use their mobile devices to augment their experience, 'seeing' energy sources to capture through the lens of their mobile phone, as in the case of Ingress, or wild Pokémon roaming the streets as in the case of Pokémon GO. What is particularly interesting about each of these cases is that the user's experience of the game relies very much on the presence of other players who compete for the same objectives, and who themselves augment the game experience, either by supporting the player's efforts to capture an objective, or by serving as opponents in Pokémon gym battles and the like.

In this way, games such as Ingress and Pokémon GO transcend the pattern of 'traditional' video games, where the majority of the content is provided in the game itself; much rather, these new mixed reality games serve more as a platform through which the players themselves become a part of the product. Without other players, the games on their own become quite boring. And yet, when hundreds or even thousands of players are all competing for the same objectives in any location, the games take on a whole new life of their own.

However, these platforms are not without their controversies. Uber in particular, frequently makes headlines on account of its often troubled relationship with its drivers (are they users or are they employees?), while its raft of new features has also thrown its obsession with standardization into sharp relief. In one recent example, the firm announced the launch of a new 'quiet mode' available to users of the premium Uber Black service (Ghajar 2019). This feature gives users the option to request their driver not talk to them during their journey by clicking on a button in the app. Naturally, this new feature has led to some consternation among Uber drivers and indeed members of the public, with some national news websites reporting the feature 'dehumanizes' drivers (Dresch 2019). 
Indeed, this same argument can also be applied to mixed reality games such Ingress and Pokémon GO. While the players themselves are not being 'paid' as employees (as in the case of Uber drivers), they are providing a form of free work, while also conforming to a set pattern of behaviour much like the standardized, robotic frameworks imposed by Uber Black. Whereas in the past, a computer game publisher may have included computer-controlled non-player characters (NPCs) to fill the game world, in Ingress and Pokémon GO, the human players become the NPCs, and so take on the mantle of automated behaviour and response.

This poses an important question: are users dehumanized in the process of using or 'playing' these digital apps, or were they dehumanized all along? Consumers want choice, and so both producers and consumers must adopt standardized modes of being that give the greatest choice within a standard template service. While some commentators may find Uber's 'quiet mode' somewhat disturbing in its implications, it is perhaps more troubling that this is a feature Uber believes that its passengers want, and one that needs to be selected via the medium of a machine. In this way, even the act of consumption itself becomes a standardized robotic act - much as it does in the works of science fiction author Frederik Pohl.

This same observation also applies to augmented or mixed reality video games such as Ingress and Pokémon GO. In each of these examples, the experience of the game depends on other users, which itself becomes a limiting factor in a player's enjoyment of the game. You don't have to travel far around many university campuses to find groups of students huddled in small groups, all staring down at their phones as they seek to capture a key location, or protect it against a rival gang. What's so telling about this example is the way the gamers themselves fall into a trap of standardized behaviour wherein their 'experience' isn't really an experience at all, but rather a pre-packaged, prearranged event where individual player agency is limited to 'be in $\mathrm{X}$ location at $\mathrm{Y}$ time', with little freedom to go beyond the standard script. In this way, players are stripped of agency, and so encouraged to behave like an NPC - a computer-controlled character that would have traditionally been programmed into the game itself.

\section{Re-inserting the human}

The implications of the robot prosumer are numerous and far reaching. While the ongoing rationalization of services may provide certain benefits to both the consumer and the producer (after all, Uber gives its drivers the opportunity to work which they otherwise might have lacked), there can be no doubting the disturbing future that a world of robotic prosumption implies. Not least is the fact that the 'choice' offered by standardized models of consumption really is no choice at all - it is merely prescription packaged as choice.

But while Frederik Pohl and his contemporaries may have long warned about the consequences of prosumption, Pohl's most important insight is perhaps the danger of removing the 
human completely. For, in the world of Pohl's robotic future-present, the ultimate prosumer isn't just one who selects or even makes the product themselves, but rather one who becomes the very product they seek to consume, and in so doing consumes a small part of themselves in the process, much like the users of social media, Uber taxi service users, and customers at Starbucks who add to the ambiance that Starbucks is seeking to sell (Ritzer 2011, 221).

So can there ever be a way out? While Alvin Toffler's original concept of the prosumer is excessively utopian in its outlook (in contrast to Ritzer's more nuanced analysis), he does at least close The Third Wave with some good advice. ${ }^{1}$ Namely, Toffler calls for all members of society to take active responsibility for change and so shape the direction of the world $(1980,453)$. It is only by exposing the presumptive practices of everyday life that social theorists can hope to draw attention to the ways in which human lives are becoming ever-more rationalized, ever-more robotic, to the detriment of genuine creativity and freedom of expression.

In order to overcome the subtraction of the human from the process of prosumption, first one must understand the problem, and the ways in which the 'human' is created as a site of contested meaning, framed relative to the non-human, the animal, and the machine. This, by its very nature, requires an interdisciplinary approach that looks beyond the social sciences to consider the broader implications of prosumption for how we define the human, and the place of the human within wider academic discourse. As such, speculative frameworks are absolutely vital to this approach. This is because they move beyond traditional siloed methods of thinking to assess the potential impacts and implications of new technology, and the links between production and consumption, technology and work. Just as Ritzer points out with his analysis of rationalist discourse, so rationalism itself can often be highly irrational in the way that it works (Ritzer 2011). This argument suggests a need for an irrational means through which to explore the impacts of prosumption, and the social change it brings about. It is only by thinking and acting irrationally, by taking the step away from the regular and the mundane that we might reinsert the human in the discourse of prosumption.

This is why science fiction is such an important tool for social theorists - it provides the means with which to test 'what if' scenarios, and speculate on what the future might bring. In the case Frederik Pohl, his worlds of hyper-consumption, robot workers and ecological disaster are even more relevant today than they were back in the 1950s. If anything, Pohl's work demonstrates how even in the mid-part of the twentieth century, science fiction was already starting to blur with science fact, such that in the twenty-first century, the two are almost one and the same. For this reason, there is a greater need than ever to take speculative frameworks more seriously in the humanities and social

\footnotetext{
${ }^{1}$ Toffler argues that the prosumer is a positive vision for the future, in which individuals benefit from having a part in the production and consumption of goods and services. Were they alive today, Pohl and Kornbluth would certainly question how such a cycle can be beneficial. This begs the question: beneficial for who?
} 
sciences - to use these tools as a means to explore the relationship between the human and the machine, and the fundamental link between production, consumption, technology and work.

$[7,957$ words $]$ 


\section{References}

Ahluwalia Pal and Toby Miller (2014) The Prosumer. Social Identities 20(4-5): 259-261.

Čapek Karel (2011) R.U.R. (Rossum's Universal Robots) and War With the Newts. London: Gollancz.

Deleuze Gilles and Félix Guattari (1987) A Thousand Plateaus: Capitalism and Schizophrenia. London: Bloomsburg.

Denegri-Knott Janice et al. (2012) Tracking Prosumption Work on EBay: Reproduction of Desire and the Challenge of Slow Re-McDonaldization. American Behavioral Scientist 56(4): 439-458.

Dick Philip K (1968) Do Androids Dream of Electric Sheep? London: Gollancz.

Dresch Matthew (2019) Uber Launches "Dehumanising" Quiet Option for Passengers Who Want Silent Drivers. Mirror, 20 May 2019. Available at: www.mirror.co.uk/news/uk-news/uberlaunches-dehumanising-quiet-option-16170888 (accessed 17 May 2019).

Ghajar Aydin (2019) Introducing an Enhanced Uber Black Experience. Available at: www.uber.com/newsroom/introducing-an-enhanced-uber-black-experience (accessed 17 July 2019).

Herman Edward S and Chomsky Noam (1988) Manufacturing Consent: The Political Economy and the Mass Media. New York: Pantheon Books.

Horáková Jana and Kelemen Jozef (2008) The Robot Story: Why Robots Were Born and How They Grew Up. In: Philip Husbands, Owen Holland and Michael Wheeler (eds) The Mechanical Mind in History. Cambridge MA: The M.I.T Press, pp. 283-306.

Izberk-Bilgin Elif and Ahuvia Aaron (2010) eBayization. In: George Ritzer (ed) McDonaldization: The Reader. California: Pine Forge Press, pp. 425-433.

Jurgensen Nathan (2010) The De-McDonaldization of the Internet. In: George Ritzer (ed) McDonaldization: The Reader. California: Pine Forge Press, pp. 159-171

Latham Rob (2014) Frederik Pohl 1919-2013. Science Fiction Studies 41(1): 233.

Lippmann Walter (1922) Public Opinion. New York: Harcourt, Brace and Company.

Luckhurst Roger (2005) Science Fiction. Cambridge: Polity Press.

MacNeil Robert (1968) The People Machine: The Influence of Television on American Politics. London: Eyre \& Spottiswoode.

Packard Vance (1957) The Hidden Persuaders. London: Longmans, Green \& Co.

Page Michael R (2015) Frederik Pohl. Springfield: University of Illinois Press.

Pohl Frederik (1966) The Man Who Ate the World. In: The Frederik Pohl Omnibus. Hertfordshire: Panther Books, pp. 7-35.

(1975) The Midas Plague. In: Lester del Rey (ed) The Best of Frederik Pohl. New York: Taplinger Publishing Company, pp. 112-161.

_(1976) Man Plus. London: Millennium. 
(2009) Gateway. London: Gollancz.

Pohl Frederik and Kornbluth CM (1960) The Space Merchants. London: Digit Books.

Ritzer George (1993) The McDonaldization of Society: An Investigation into the Changing Character of Contemporary Life. London and New Delhi: Pine Forge Press.

(1998) The McDonaldization Thesis. Sage: London.

(2010) Enchanting a Disenchanted World: Revolutionizing the Means of Consumption, 3rd ed. Pine Forge Press: Thousand Oaks, CA.

(2011) The McDonaldization of Society 6. California: Sage.

(2015) Prosumer Capitalism. The Sociological Quarterly 56(3): 413-445.

Ritzer G and Chen C (2015) McDonaldization. In: International Encyclopedia of the Social \& Behavioral Sciences, 2nd ed. Available at: http://dx.doi.org/10.1016/B978-0-08-0970868.64125-9 (accessed 24 July 2019).

Ritzer G and Jurgenson N (2010) Production, Consumption, Prosumption: The Nature of Capitalism in the Age of the Digital 'Prosumer'. Journal of Consumer Culture 10(1): 13-36.

Ritzer G and Miles S (2019) The Changing Nature of Consumption and the Intensification of McDonaldization in the Digital Age. Journal of Consumer Culture 19(1): pp.3-20.

Ryder, M J (2019) Microfascism and the Double Exclusion in 'Flowers for Algernon'. Foundation: The International Review of Science Fiction 48(1): 54-65.

Toffler A (1980) The Third Wave. New York: William Morrow.

Zuboff, Shoshana (2019) The Age of Surveillance Capitalism: The Fight for the Future at the New Frontier of Power. London: Profile Books. 